\title{
At the Limits of Cultural Heritage Rights? The Glasgow Bajuni Campaign and the UK Immigration System: A Case Study
}

\author{
Emma C. Hill*
}

\section{Máiréad Nic Craith ${ }^{\dagger}$}

\section{Cristina Clopot C $^{\ddagger}$}

\begin{abstract}
In 2003, the Convention for the Safeguarding of Intangible Cultural Heritage (UNESCO ICH Convention) formalized provision for forms of heritage not solely rooted in the material world. This expanded the scope and accessibility of cultural heritage rights for communities and groups. To much commentary and critique, the United Kingdom (UK) infamously decided not to ratify the UNESCO ICH Convention. This article examines the implications of the UK's decision not to ratify the Convention for the cultural heritage and human rights of an asylumseeking group in Glasgow, Scotland, namely, the Glasgow Bajuni campaigners, members of a minority Somali clan. Based on participatory ethnographic fieldwork with the group and analysis of their asylum cases, this article makes two observations: first, that the UK's absence from the Convention establishes a precedent in which other state actors (that is, immigration authorities) are emboldened to advance skepticism over matters involving intangible cultural heritage and, second, that despite this, limitations in current provisions in the UNESCO ICH Convention would provide the group with little additional protection than they currently have. Developing these observations, we critique current UK approaches to intangible cultural heritage as complicit in the maintenance of hierarchies and the border. Finally, we consider the extent to which the current provisions of the UNESCO ICH Convention might be improved to include migrant and asylum-seeking groups.
\end{abstract}

\footnotetext{
${ }^{\star}$ Research Fellow, Sociology, School of Social and Political Sciences, University of Edinburgh, Edinburgh, UK; Email: ech2@hw.ac.uk

${ }^{\dagger}$ Research Assistant, School of Social Sciences, Heriot-Watt University, Edinburgh, UK;

Email:c.clopot@hw.ac.uk

\#Director of Research, School of Social Sciences, Heriot-Watt University, Edinburgh, UK;

Email: m.niccraith@hw.ac.uk
} 
Keywords: intangible cultural heritage, human rights, cultural rights, asylum seekers, Bajuni, Somali, immigration

In recent decades, the relationship between cultural heritage and human rights has become a focus of discussion. Scholars have increasingly recognized a person's access to cultural heritage as a fundamental right ${ }^{1}$ and noted that cultural heritage is often connected to a person's right to broader social expression and other human rights. ${ }^{2}$ This growing recognition of the links between cultural heritage rights and human rights has contributed to, and extended into, discussions about the status of intangible cultural heritage. Intangible cultural heritage was formally recognized in the 2003 Convention for the Safeguarding of Intangible Cultural Heritage (UNESCO ICH Convention). ${ }^{3}$ Although the Convention is not without problems, it has provided the first instance of formal recognition to forms of heritage that were not solely rooted in the material world (the built environment, material artifacts, and so on). By expanding the scope of heritage to include intangible forms of cultural expression, the UNESCO ICH Convention redefined heritage as something that was living, practiced, and elastic. ${ }^{4}$ For the first time, communities whose heritage largely manifested in intangible, rather than tangible, forms of expression had specific and formalized access to the protections of the United Nations Educational, Scientific and Cultural Organization (UNESCO). Although the state nonetheless remained involved in nominating a community's intangible cultural heritage for protection, this meant that UNESCO's provisions were a little more accessible for communities and minority groups with primarily intangible cultural heritage. ${ }^{5}$

The United Kingdom (UK) has rather infamously decided not to ratify the UNESCO ICH Convention. The UK government has sought to justify this decision on the basis that intangible cultural heritage is given provision in other instruments to which it is a signatory. ${ }^{6}$ However, Laurajane Smith, Emma Waterton, and Natsuko Akagawa have suggested that the UK's reluctance to ratify the Convention must be understood instead in the context of the UK's dominant heritage discourse, which continues to emphasize heritage in tangible, fixed terms. ${ }^{7}$ The lack of a UK signature to the Convention has prompted concern among community groups and

\footnotetext{
${ }^{1}$ Silverman and Ruggles 2007; Logan, Langfield, and Nic Craith 2010; Farida Shaheed, "Report of the Independent Expert in the Field of Cultural Rights," Doc. A/HRC/17/38, 21 March 2011, http://www. refworld.org/docid/50f01fb12.html (accessed 23 March 2017).

${ }^{2}$ Convention on the Protection and the Promotion of the Diversity of Cultural Expressions, 20 October 2005, 2440 UNTS 311 (hereafter Cultural Expression Convention).

${ }^{3}$ Convention for the Safeguarding of Intangible Cultural Heritage, 17 October 2003, 2368 UNTS 1 (hereafter UNESCO ICH Convention).

${ }^{4}$ General Comment no. 21 on the Right of Everyone to Take Part in Cultural Life, Doc. E/C.12/GC/21, 21 December 2009, http://www.refworld.org/docid/4ed35bae2.html (accessed 7 May 2017), Art. 11.

${ }^{5}$ Albeit with some limitations. See Logan 2009.

${ }^{6}$ Smith, Waterton, and Akagawa 2009; see also Hassard 2008.

${ }^{7}$ Smith, Waterton, and Akagawa 2009, 297.
} 
advocates, who fear that their particular expressions of intangible cultural heritage will suffer from a lack of specialized protection. ${ }^{8}$ However, others have suggested that minority and vulnerable populations might in fact encounter some benefits of remaining outside the Convention. For instance, William Logan suggests that ratification of the Convention has the potential to place minority groups in vulnerable positions, especially in cases where communities are not really involved in the prior process of assessment or in cases where "authorized discourses" 9 occlude the approaches of minority groups to intangible cultural heritage. These cases, Hall notes, "are always inflected by the power and authority of those who have colonised the past, whose versions of history matter." 10 In instruments such as the UNESCO ICH Convention, in which the state has final responsibility for submitting nomination dossiers, ${ }^{11}$ there is therefore potential for the cultural heritage and the human rights of minority groups to be subordinated to the priorities of the state. ${ }^{12}$

Since the UK has continued to decline to sign the UNESCO ICH Convention, discussions about the potentials and pitfalls of the UK's (non-)ratification of the Convention have remained literally and figuratively academic. Interactions between cultural heritage rights and human rights and between rights to intangible cultural heritage and the UNESCO ICH Convention are complex, messy, and have multiple possible outcomes for future intangible cultural heritage provisions, for the state, and for the communities within it. A better understanding of the full implications-and multiple possible outcomes - of the UK's stance both on the UNESCO ICH Convention and on its relationship to human rights is therefore overdue. Moreover, we would suggest, the analysis of this relationship must be grounded in the empirical experiences of groups and communities living with the outcomes of the current situation in the UK.

With such a goal in mind, this article explores the context of the experiences of the Glasgow Bajuni campaign. The experiences of the campaigners have been gathered over two years of ethnographic participatory research in Glasgow, Scotland. ${ }^{13}$ Based in Glasgow, the Glasgow Bajuni campaign ran between 2013 and 2015 and was a grassroots campaign that protested the experiences of a small group of Somali Bajuni people seeking asylum in the UK. The asylum applications of all seven members of the campaign group had been repeatedly refused by the UK immigration authorities. The campaigners' cases had been built—and rejected—on iterations of their intangible cultural heritage, including their knowledge of Bajuni

\footnotetext{
${ }^{8}$ Howell 2008.

${ }^{9}$ Logan 2009; Smith 2006.

${ }^{10}$ Hall 2005, 6.

${ }^{11}$ Kuutma 2013.

${ }^{12}$ Harrison 2013, 136.

${ }^{13}$ Fieldwork was conducted in Glasgow between January 2014 and December 2015. It combined ethnographic ontologies with participatory research methods (Phipps 2013). Emma Hill assisted the group with their campaigning work and provided administrative, research, and social support to campaign members. Due to the sensitivity of the campaigners' cases, no formal interviews were recorded, but their comments and perspectives were noted as part of the long-term participant observation that accompanied the participatory research.
} 
cultural practices and their abilities in Bajuni languages. ${ }^{14}$ Following the refusal of their asylum applications, the campaigners have faced prolonged destitution and possible detention and deportation. Considered in terms of cultural and human rights, the Glasgow Bajuni campaigners' cases raise a number of complexities. First, the centrality of language to the Bajuni campaigners' cases is a controversial issue, not only within the context of their asylum applications ${ }^{15}$ but also as an instance of intangible cultural heritage. ${ }^{16}$ Second, the location of the campaigners' cases within the UK's asylum infrastructure merges questions about cultural heritage rights with fundamental human rights. Under the 1948 Universal Declaration of Human Rights, the act of seeking asylum is identified as a fundamental human right. ${ }^{17}$ This right is further enshrined by the 1951 UN Convention Relating to the Status of Refugees. ${ }^{18}$ In these circumstances, there is an argument to be made that by dismissing the intangible cultural heritage upon which the Bajuni campaigners' cases are built, the UK Immigration authorities are placing their fundamental human right to seek asylum and freedom from persecution at risk. Furthermore, one might argue, if this human right is placed at risk, so too are the campaigners' cultural heritage rights. ${ }^{19}$ One might also ask whether the Immigration authorities' dismissal of the campaigners' intangible cultural heritage is informed by a skepticism toward intangible cultural heritage and cultural heritage rights.

A key question, therefore, is to what extent does the UK government's refusal to ratify the UNESCO ICH Convention impact the Glasgow Bajuni campaigners' asylum cases? Is the denial of both their asylum applications and their intangible cultural heritage a result of the fact that intangible cultural heritage does not have the protection of the UNESCO ICH Convention? Or is the reverse in fact the case: does the UK's status outside the Convention not have an impact upon matters of intangible cultural heritage? These questions are evidently of relevance in the specifics of the UK context; however, because they interrogate the effectiveness of the Convention, they also have a wider scope. There are also questions raised by the Bajuni campaigners' cases about migrants - and especially asylum seekers, who are at the margins of the state- and the the extent to which they should be given provision and protection in current cultural heritage instruments.

We address these questions throughout this article. To begin, we first review existing discussions about the relationship between cultural heritage and human rights. In the second section of the article, we discuss the details of the Bajuni

\footnotetext{
${ }^{14} \mathrm{All}$ names included in this article were changed to protect the identity of the informants.

${ }^{15}$ In the United Kingdom (UK), the testing of language to determine a person's country of origin is regarded as a controversial and flawed process (see section "The Bajuni Campaign in Glasgow, UK” below). ${ }^{16} \mathrm{Nic}$ Craith 2008. The status of language as part of a community's intangible cultural heritage remains contested and unrecognized (see section "Cultural Heritage and Human Rights" below).

${ }^{17}$ Universal Declaration of Human Rights, UN Doc. A/810, 10 December 1948.

${ }^{18}$ Convention Relating to the Status of Refugees, 28 July 1951, 189 UNTS 150, Art. 1.

${ }^{19} \mathrm{As}$ if their asylum claims are not accepted, they are at risk of being returned to a country in which their cultural heritage makes them vulnerable.
} 
campaigners' cases, and, in the final section, we evaluate the extent to which intangible cultural heritage provisions are of benefit or detriment to the campaigners' situation. We conclude with observations about the current limitations and potentials of contemporary intangible cultural heritage instruments.

\section{CULTURAL HERITAGE AND HUMAN RIGHTS}

Despite receiving increased attention in recent years, the relationship between cultural heritage and human rights_-and, more specifically, the provision made for this relationship-remains on rather uncertain ground. ${ }^{20}$ Overt attempts to discuss cultural heritage within United Nations (UN) human rights instruments have not been forthcoming, and Lucas Lixinski has noted a degree of reticence on the part of the UN to incorporate cultural heritage into its body of treaties. ${ }^{21}$ The presence of heritage in human rights legislation is scant, limited to Article 15 of the International Covenant on Economic, Social and Cultural Rights (ICESCR) 22 and Article 27 of the International Covenant on Civil and Political Rights (ICCPR), which recognizes the rights of minorities to "enjoy their own culture, to profess and practice their own religion, or to use their own language." 23 However, despite these initial provisions, cultural heritage rights have received insufficient consideration in human rights instruments. Sophia Labadi has suggested that while cultural heritage rights are considered problematic in a human rights context, they also remain under-problematized. ${ }^{24}$ Certainly, the issue does not have an easy resolution for, as Logan observes, discussions both of heritage and of human rights in a global context must take into account a plethora of distinct national, cultural, or political approaches to the topic as well as remaining aware of national and global hierarchies of power involved in any potential mobilization. ${ }^{25}$ In this context, Yvonne Donders observes, issues arise because "states do not always agree whether cultural rights are substantive human rights or more policy-oriented human rights that do not impose direct, definite obligations." 26

In noticeable contrast to the (under-)provision of heritage rights in human rights instruments, cultural heritage legislation has given human rights some provision. Although older instruments such as the 1972 Convention Concerning the Protection of the World Cultural and Natural Heritage initially established a weak

\footnotetext{
${ }^{20}$ Silverman and Ruggles 2007; Logan, Langfield, and Nic Craith 2010; Shaheed, "Report on Cultural Rights."

${ }^{21}$ Lixinski 2013.

${ }^{22}$ Which states that everyone should have the right to participate in cultural life. International Covenant on Economic, Social and Cultural Rights, 16 December 1966, 993 UNTS 3.

${ }^{23}$ International Covenant on Civil and Political Rights, 16 December 1966, 999 UNTS 171, Art. 27 (hereafter ICCPR).

${ }^{24}$ Labadi 2010.

${ }^{25} \operatorname{Logan} 2009$.

${ }^{26}$ Donders 2010, 32.
} 
link with human rights, the relationship has since been reconsidered and partially readdressed. ${ }^{27}$ The special rapporteur in the field of cultural rights, Farida Shaheed, considers cultural heritage rights as fundamental human rights, ${ }^{28}$ noting that "access to and enjoyment of cultural heritage as a human right is a necessary and complementary approach to the preservation/safeguard of cultural heritage." ${ }^{29}$ The 2005 Framework Convention on the Value of Cultural Heritage for Society (Faro Convention) echoes Shaheed's comments:

[E]very person has a right to engage with the cultural heritage of their choice, while respecting the rights and freedoms of others, as an aspect of the right freely to participate in cultural life enshrined in the United Nations Universal Declaration of Human Rights (1948) and guaranteed by the International Covenant on Economic, Social and Cultural Rights (1966)..$^{30}$

The Faro Convention makes explicit reference to its commitment to human rights, stating:

No provision of this Convention shall be interpreted so as to:

(a) limit or undermine the human rights and fundamental freedoms which may be safeguarded by international instruments, in particular, the Universal Declaration of Human Rights and the Convention for the Protection of Human Rights and Fundamental Freedoms. ${ }^{31}$

However, although the Convention's explicit link between cultural heritage provision and human rights is to be welcomed, it must also be questioned whether the provision goes far enough. Further additions to Article 6 clarify the Convention's position and note that implementations of its provisions should not:

(b) affect more favourable provisions concerning cultural heritage and environment contained in other national or international legal instruments; (c) create enforceable rights. ${ }^{32}$

Though the Faro Convention's stated commitment to the relationship between human and heritage rights is a step in the right direction on paper, its ambitions remain rather hollow in practice, not only unenforceable but also subordinated to pre-existing treaties and instruments that have fewer human rights provisions. While there is more leeway within this framework for unofficial expressions of heritage, such as those of minorities, its remit is curtailed by its

\footnotetext{
${ }^{27} \operatorname{Logan} 2008$. Convention Concerning the Protection of the World Cultural and World Heritage, 23 November 1972, 1037 UNTS 151 (hereafter Natural Heritage Convention).

${ }^{28}$ Shaheed, "Report on Cultural Rights."

${ }^{29}$ Shaheed, "Report on Cultural Rights," 3.

${ }^{30}$ Framework Convention on the Value of Cultural Heritage for Society, 27 October 2005, CETS no. 199, preamble (hereafter Faro Convention).

${ }^{31}$ Faro Convention, Art. 6.

${ }^{32}$ Faro Convention, Art. 6.
} 
regional emphasis, and further development of international standards is needed in order to advance rights.

While the Faro Convention leaves considerable work to be done of cementing the relationship between cultural heritage and human rights, it is nonetheless of note for its innovative and expansive use of the concept of heritage, ${ }^{33}$ which places emphases on cultural heritage as defined by "no inherent time limits, nor limits of form and manifestation." 34 In this context, it has had some success in making provision for forms of cultural heritage beyond the established definitions, which in the past have focused on an understanding of heritage as embodied in items, identified by experts rather than by people of the community and arranged in a global hierarchy of value based on assigned "outstanding universal value." 35 The Convention follows moves by UNESCO to broaden its definition of heritage, moving from materiality to a processual understanding that also incorporates intangibility. ${ }^{36}$ UNESCO's work has been embodied in instruments such as the 2005 Convention on the Protection and Promotion of the Diversity of Cultural Expressions ${ }^{37}$ and the UNESCO ICH Convention. ${ }^{38}$ The UNESCO ICH Convention espouses a definition of cultural heritage that emphasizes practiced, lived, and living understandings, which include

intangible cultural heritage, [which is] transmitted from generation to generation, [and] is constantly recreated by communities and groups in response to their environment, their interaction with nature and their history, and provides them with a sense of identity and continuity, thus promoting respect for cultural diversity and human creativity. ${ }^{39}$

The UNESCO ICH Convention also takes care to note the relationship between intangible cultural heritage and human rights:

For the purposes of this Convention, consideration will be given solely to such intangible cultural heritage as is compatible with existing international human rights instruments, as well as with the requirements of mutual respect among communities, groups and individuals, and of sustainable development. ${ }^{40}$

The UNESCO ICH Convention's dual emphasis upon international human rights legislation and the requirements of communities and groups recognizes the relationship between intangible cultural heritage and human rights as an issue that is both locally and (inter)nationally constituted, and it requires human rights legislators

\footnotetext{
${ }^{33}$ Jokilehto 2012.

${ }^{34}$ Fairclough 2009, 37.

${ }^{35}$ See, e.g., World Heritage Convention.

${ }^{36}$ Bortolotto 2006, 2007.

${ }^{37}$ Cultural Expression Convention.

${ }^{38}$ UNESCO ICH Convention.

${ }^{39}$ UNESCO ICH Convention, Art. 2.

${ }^{40}$ UNESCO ICH Convention, Art. 2.
} 
to work with specific cultural, social, and political approaches to rights espoused by communities and groups. The emphasis on the perspectives of communities and groups is important because it challenges normative approaches (such as those noted in the Faro Convention), which place the requirements of international legislation above the local practices of communities and groups. The increased focus on the requirements of communities and groups might be read alongside later provisions made for minority and Indigenous peoples, such as the UN Declaration on the Rights of Indigenous Peoples (UNDRIP), which notes that "indigenous peoples have the right to maintain, control, protect and develop their cultural heritage, traditional knowledge and traditional cultural expressions, "41 or the recent Organization of American States American Declaration on the Rights of Indigenous Peoples (American Declaration), which in many ways pushes the UNDRIP's provisions on heritage to a whole new level. ${ }^{42}$ These approaches have begun to embed Indigenous and minority forms of knowledge and heritage into rights-based frameworks. Former Special Rapporteur on the protection of the heritage of Indigenous peoples, Erica Daes, comments: "[S] uch legal reforms are vital to a fair and legal order because indigenous peoples cannot survive or exercise their fundamental human rights as distinct nations, societies and peoples without the ability to conserve, revive, develop and teach the wisdom they have inherited from their ancestors." 43

It is important to note that though the UNESCO ICH Convention preempts a move toward these more recent attempts to connect minority and Indigenous heritage with a rights-based context, it does not pursue the matter to the same extent as the American Declaration. Perhaps, as a result, the UNESCO ICH Convention has continued to omit elements of intangible cultural heritage that are of key importance to local groups and communities from its provisions. Language is an example of one such exclusion. Although language is included within the UNESCO ICH Convention, Article 2a refers to language simply as "a vehicle of the intangible cultural heritage." ${ }^{4}$ The neglect of language as an explicit dimension of heritage has been raised as being problematic by some absentees from the Convention. ${ }^{45} \mathrm{We}$ argue that this demotes the status of language to "a vehicle of transmission rather than a dimension of heritage to be valued in and of itself." 46 As we have noted elsewhere and as is apparent

\footnotetext{
${ }^{41}$ United Nations Declaration on the Rights of Indigenous Peoples, GA Res 61/295, UN GAOR, UN Doc A/RES/61/295, 13 September 2007, Art. 31.

${ }^{42}$ American Declaration on the Rights of Indigenous Peoples, AG/RES.2888 (XLVI-O/16), 15 June 2016.

${ }^{43}$ Erica Daes, Sub-Commission on Prevention of Discrimination and Protection of Minorities, Commission of Human Rights, United Nations Economic and Social Watch, "Study on the Protection of the Cultural and Intellectual Property Rights of Indigenous Peoples," Doc. E/CN.4/Sub.2/1992/28, $1992,13$.

${ }^{44}$ UNESCO ICH Convention, Art. 2a.

${ }^{45}$ See Nic Craith, Kockel, and Lloyd, forthcoming; Benjamin Sullivan, "Intangible Cultural Heritage in New Zealand/Aotearia: A National Perspective," 6 June 2012, https://www.baldwins.com/news/ intangible-cultural-heritage-in-new-zealand-aotearoa-a-national-perspective (accessed 21 February 2017); African Union 2006.

${ }^{46} \mathrm{Nic}$ Craith 2008, 57.
} 
in the Bajuni campaigners' cases below, if the robust enforcement of human rights provisions is lacking for matters of both tangible and intangible cultural heritage, it is especially the case for cultural practices, such as language, which are so far unrecognized as intangible cultural heritage. ${ }^{47}$ This "backdooring" of language in such important instruments has significant consequences for minorities. ${ }^{48}$

\section{THE UK AND THE UNESCO ICH CONVENTION}

The UK's context within which the case study of this article is set provides additional complications to an already complex dynamic between human and cultural heritage rights. The UK has signed and ratified both the ICESCR and the ICCPR. These documents include provisions related to participation in cultural life, broadly discussed, that include the right of minorities to "enjoy their own culture, to profess and practice their own religion, or to use their own language." 49 However, despite its close involvement in the development of other UNESCO instruments, the UK has not ratified the UNESCO ICH Convention. Ostensibly, the UK government has argued against ratifying the UNESCO ICH Convention on the basis that it considers that provisions for intangible cultural heritage are covered by the broad references to cultural heritage in earlier instruments. Smith and Waterton suggest otherwise..$^{50}$ They argue that the UK refuses to ratify the UNESCO ICH Convention because it presents a view of heritage that is in conflict with normative UK heritage precedents, which see heritage as "in the past and an end product in itself." 51 As a result, they suggest that approaches to heritage in the UK have "started to stagnate around a view of identifying national importance, establishing objective and immutable value of aesthetics and authenticity." 52 The UK is not the only nation-state to have not ratified the treaty. Richard Kurin notes that "several nations with a history tied to the UK-the US, Canada, Australia and New Zealand-have not signed on" because of "how the Convention might affected historic and legally complex relationships with their native populations." 53 To what extent might the UK's approach to minority groups also factor into the decision not to ratify the UNESCO ICH Convention? To what extent does it find the Convention's emphasis on the requirements of minority groups and communities problematic?

\footnotetext{
${ }^{47} \mathrm{Nic}$ Craith and Hill 2015.

${ }^{48}$ Lixinski 2013, 162.

${ }^{49}$ ICCPR, Art. 27.

${ }^{50}$ Smith, Waterton, and Akagawa 2009.

${ }^{51}$ J. Orr, "Building and Sharing ICH Information: Experts," meeting report, 2011, http://www. ichcap.org/eng/ek/sub8/pdf_file/03/2011_Expert_Meeting_Report.pdf (accessed 13 November 2017), 50.

${ }^{52}$ Orr, "Building and Sharing ICH Information: Experts," 50, who comments on Smith, Waterton, and Akagawa 2009.

${ }^{53}$ Quoted in Stefano 2016, 41.
} 
In the more general context of the relationship between human and heritage rights, and in the specific immigration context of this article, the UK's failure to ratify the UNESCO ICH Convention raises a number of questions. The first question concerns impact and asks: what are the immediate consequences of the UK's lack of recognition of the UNESCO ICH Convention for cases that rely on iterations of intangible cultural heritage? What about iterations of cultural heritage (such as language) that remain unrecognized even by the UNESCO ICH Convention? How are the human rights of the individuals involved in these cases impacted? The second question raises points about framing and precedent and asks: to what extent does the UK's rejection of the UNESCO ICH Convention normalize particular definitions of, and approaches to, cultural heritage? How does this precedent influence other state actors involved in the evaluation of cultural heritage? The third considers this question of impact beyond this specific case and casts a critical eye over the potential of the UNESCO ICH Convention to impact human rights. It asks to what extent do such cases suffer from the fact that the UK has not ratified the Convention? Or, following Logan's point that state ratification of the UNESCO ICH Convention can impede, rather than increase, minority groups' access to human rights, ${ }^{54}$ to what extent might they benefit from it? To answer these broader questions, we first turn to the specifics of our case study.

\section{CASE STUDY: THE GLASGOW BAJUNI CAMPAIGN}

The Glasgow Bajuni campaign began in the autumn of 2013. Formed as a last resort for its near destitute members, it sought to raise awareness of the significant difficulties a small group of campaigners were encountering with their asylum applications to the UK. The campaigners were all members of the Bajuni clan, a minority clan from the southern regions of Somalia, which has encountered considerable persecution due to its minority status. On account of this persecution, many from the clan have fled Somalia and sought refuge in countries around the world. On claiming asylum in the UK, the Bajuni group were required to complete a series of linguistic and cultural tests which, in the absence of documentation, were used to identify their nationality. This form of testing has been used by the UK Home Office since 2004. ${ }^{55}$ The following section gives some cultural and historical context to the Bajuni's situation before tracing the ways in which their cultural and linguistic heritage is problematized in a rights-based context.

\section{Who Are the Bajuni People?}

Following unrest in Somalia in 1969, the outbreak of civil war in 1991, and after decades of continuing conflict, the Bajuni people have been displaced

\footnotetext{
$\overline{{ }^{54} \operatorname{Logan} 2} 009$.

${ }^{55}$ Peter L. Patrick, "Language Testing of Asylum Seekers," 2014, Language and Asylum Research Group: Papers Online, http://privatewww.essex.ac.uk/ patrickp/ (accessed 9 May 2017).
} 
all over the world. ${ }^{56}$ However, those remaining in Somalia live on the coast of the Jubba Hoose region in the Bajuni-founded port city of Kismayo and on the Bajuni Islands archipelago. The term "Bajuni" is used to describe a person's overall membership in the Bajuni "tribe," which itself is broken into 18 smaller "clans." 57 The Bajuni people have traditionally made their living by way of the sea-through fishing, trade, or seamanship-or by cultivating land on the coast of the mainland. ${ }^{58}$ Traditionally, the Bajuni people have spoken Kibajuni, a language related to, but distinct from, Swahili. In more recent years, due to trade, travel, and displacement, Swahili and some Somali has also become more common. ${ }^{59}$

In Somalia, the Bajuni have encountered persecution on multiple counts. ${ }^{60}$ In addition, though it is not the only factor in their ongoing oppression and should not be viewed in isolation, the Bajuni's clan identity and relationship to the wider Somali clan system has been influential in their persecution. ${ }^{61}$ In the wider Somali context, clan provides a structure of social stratification. Based on long paternal lineages, the clan system stratifies Somali people into majority and minority clans and sub-clans. The social status of a clan is informed by a number of elements. Somali origin narratives confer clan status and social belonging based on their perceived proximity to Arab ethnicity and Islam. ${ }^{62}$ Territorial and lifestyle associations further determine status, with the (northern) territories and the (nomadic) lifestyles of those with most status given precedence. ${ }^{63}$ Based on these categories, clans are organized into an (ever-evolving) hierarchy, which is bound by a common ancestry. The Bajuni people are not located in this clan hierarchy. With a mix of African, Arab, and Portuguese origins, their ancestry is associated not with the Somali lineage system ${ }^{64}$ but, rather, with the peoples that historically occupied the ancient African kingdoms in Central East Africa. ${ }^{65}$ Today, on the basis of their language, ${ }^{66}$ they can be associated with Bantu ethnicity. ${ }^{67}$

As a result of their differing lineage and culture, the Bajuni people are widely considered to be outside the dominant Somali clan system and are often defined as a non-lineal, non-ethnic Somali minority clan. Their non-lineal status can be

\footnotetext{
${ }^{56}$ Besteman 2012.

${ }^{57}$ D. Nurse, "Bajuni: People, Society, Geography, History, Language: African Language Technology," 2013, aflat.org/files/dnurse/Bajuni.pdf (accessed 15 March 2017), 15.

${ }^{58}$ Nurse, "Bajuni," 2-3.

${ }^{59}$ Nurse, "Bajuni."

${ }^{60}$ Kusow 2004; Abby 2005; Eno 2008.

${ }^{61}$ Kapteijns 2004.

${ }^{62}$ Ahmed 1995; Kusow 2004; Mire 2016.

${ }^{63}$ Kusow 2004, 3.

${ }^{64}$ Nurse, "Bajuni," 23.

${ }^{65}$ Eno 2008, 138.

${ }^{66}$ Nurse, "Bajuni," 37.

${ }^{67}$ Besteman 2012.
} 
connected to a long history of enslavement and exploitation by both majority clans and colonial settlers. ${ }^{68}$ Today, they are referred to derogatively as adoon (Somali for "slave") or tiku (Swahili for "slave"), ${ }^{69}$ and their non-ethnically "Somali" origins are racially denigrated. ${ }^{70}$ In the onset of the civil war, the majority clans sought to recruit Bajuni people to their cause, while violently "clearing" the Bajuni people from their traditional lands. ${ }^{71}$ In the 2000s, as the Somali state collapsed, the extremist group al-Shabaab took over southern Somalia, including the Bajuni territories, and continued the persecution of minority groups. As Derek Nurse explains, following decades of violence, ethnic cleansing, and enslavement, "no one can be sure how many Bajuni remain in Somalia but an informed guesstimate would be at most a few hundred." 72

\section{The Bajuni Campaign in Glasgow, UK}

The Bajuni campaigners arrived in the UK in the mid 2000s and were moved to Glasgow under the government's Dispersal Scheme. ${ }^{73}$ UK country guidance recommends that the Somali Bajuni be considered for asylum because they are a persecuted minority people (discussed further below). ${ }^{74}$ The Bajuni people's lifestyle on the Bajuni Islands and their often sudden means of departure has meant that many of those seeking asylum in the UK arrive without documentation, which is required by the Home Office to provide evidence of their asylum claim. ${ }^{75}$ As a result, the Home Office often requires them to submit alternative forms of evidence of their place of origin, including undergoing Language Analysis for Determination of Origin (LADO). In the absence of documentation as proof of nationality, LADO is used by a number of countries, including the UK, as one of a number of elements that can determine an asylum seeker's nationality. ${ }^{76}$ Based on guidance from linguistics experts, LADO works from the premise that a person's place of origin can be indicated (but not proven) through an analysis of a combination of a person's mother tongue, accent, and cultural knowledge of language use. ${ }^{77}$

For some Bajuni people, LADO testing has led to successful asylum applications in the UK. However (as we discuss further below), the implementation of LADO

\footnotetext{
${ }^{68}$ Besteman 1999; Kusow 2004, 3; Eno 2008, 140; Nurse, “Bajuni,” 24.

${ }^{69}$ Bajuni Campaign, "Bajuni Campaign: Seeking Justice for Glasgow Bajunis," 2014, bajunicampaign. wordpress.com (accessed 15 March 2017).

${ }^{70}$ Bajuni are referred to as jareer, a term that means "hard-textured hair" of people with "African" features and is contrasted with jilec, meaning traditional "soft-textured hair" that is associated with lineal Somalis. Kusow 2004, 4.

${ }^{71}$ Abby 2005, 14, 40.

${ }^{72}$ Nurse, "Bajuni," 2.

${ }^{73}$ Schuster 2004; Zetter, Griffiths, and Sigona 2005; Hynes 2011.

${ }^{74}$ Home Office 2015, 4.

${ }^{75}$ Griffiths 2012; see Amnesty International 2012.

${ }^{76}$ Craig 2012.

${ }^{77}$ Patrick, "Language Testing of Asylum Seekers."
} 
testing has been found to be inconsistent, and it has also been implicated in cases in which applications are considered to have been wrongly refused. ${ }^{78}$ In all of the cases of the Glasgow Bajuni campaigners, it led to their cases being refused on the grounds of "disputed nationality." The Glasgow Bajuni campaign began in the autumn of 2013 in reaction to this outcome; the seven members of the campaign (six men and one woman, plus additional supporters) were brought together by a local activist who noticed the similarities in their cases. On their blog, the campaigners state their case:

Just because they know that Somalia from mainland do not accept us as people from Somali that's why Home Office doing this to us, treating us like animals in the streets without their owners. You know what ... I'm so tired with this kind of life ... We are human too just like them, so why they doing this to us? We didn't ask God to make us Bajunis, but we are happy that we are Bajunis, even if we're from minority tribe and small in number but all we ask is to be recognised the way we are and where we are from. ${ }^{79}$

At the time of the campaign's formation, all of the campaign members had reached a point in their applications in which they were considered "appeal rights exhausted." This meant that they were no longer able to access the basic support systems usually available to people seeking asylum in the UK. As a result, life in Glasgow for the campaigners was increasingly tough. Mohamed wrote a letter to the Home Office to describe the impact of its decision on his everyday life:

It's been 5 months now since Home Office stop supporting me. Since then, I end up being a beggar to the people and different Churches but now I am fed up with this situation. I think it is better for me to be killed by Al-Shabab and those who used to torturing us before, back home there than just staying here and killed softly by hunger in the country which believe itself that have and support Human Rights. ${ }^{80}$

Once the Bajuni campaigners had exhausted their appeal rights, they entered an ill-defined area of the UK asylum system. Although they had been refused asylum, the Home Office seemed to acknowledge that it was unable to "return" them; however, it refused to give further consideration to their cases. After the refusals, the campaigners themselves could not return to Somalia as it remained an unsafe environment and were instead caught in a constant administrative process of applying for sufficient support to avoid becoming destitute. For Mohamed, the Home Office's decision against his asylum application impacted every area of his life in the most challenging of ways. From his perspective, he could see the clear links between (the denial of his) Bajuni heritage and the broader spectrum of human rights, but he was powerless to make the same links clear to those who had power over his case.

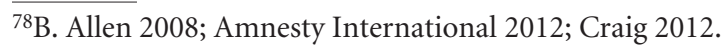

${ }^{79}$ Bajuni Campaign, 17 November 2013.

${ }^{80}$ Private correspondence to Home Office, 2014.
} 


\section{Linguistic and Cultural Heritage}

For the Glasgow Bajuni campaigners, the successes of the asylum cases were closely related to the testing of their linguistic and cultural heritage. The success of their cases rested on their ability to prove their place of origin (the Bajuni territories), their nationality (Somali), and their ethnicity (Bajuni). In the absence of documentation, the UK's Home Office instead required that they fulfil the requirements set out in Somalia v. Secretary of State for the Home Department, an immigration test case for establishing Bajuni identity. ${ }^{81}$ The requirements explicitly target aspects of the Bajuni peoples' linguistic and cultural heritage. It states:

What is needed therefore in cases in which claims to be Somali nationals and Bajuni clan identity are made is first of all: ...
(a) knowledge of Kibajuni;
(b) knowledge of Somali depending on the person's personal history;
(c) knowledge of matters to do with life in Somalia for Bajuni (geography, customs, occupations etc.). ${ }^{82}$

Based on these requirements, the campaigners initially completed a series of language tests, both through professional language-testing companies and in immigration court. However, both the testing procedures themselves and the interpretation of their results by the UK immigration authorities soon proved problematic.

For instance, Nafiz was required to undergo formal LADO testing with a (then) government-approved testing company, Sprakab. Until 2014, Sprakab was a UK government-approved LADO testing company that employed language "experts" to evaluate through linguistic means the nationality of asylum seekers who had arrived in the UK without documentation. ${ }^{83}$ The tests involved several components that evaluated the "level" of their language (ranging from "native level" to "elementary level'), alongside their use of phonology and prosody and their morphology and syntax for traces of linguistic habits specific to the area from which the asylum seeker said they came. The tests were meant to be conducted by a native speaker of the language in question, with "expert" knowledge of the context from which the applicant came. ${ }^{84}$ However, as the campaigners' cases demonstrate, these standards were often not met, while the rigours of the linguistic testing rarely allowed for the ways in which the cultural and social upheaval in Somalia had affected language habits.

\footnotetext{
${ }^{81}$ Somalia v. Secretary of State for the Home Department, Asylum and Immigration Tribunal/ Immigration Appellate Authority CG, [2004], UKIAT 00271 (Minority Clans-Bajuni-Ability to Speak Kibajuni).

${ }^{82}$ Somalia v. Secretary of State.

${ }^{83}$ Following a Supreme Court ruling in 2014 that cast doubt on its practices, Sprakab is no longer used by the UK government for language analysis for determination of origin (LADO) testing. Victoria Weldon, "Hundreds of Cases Set for Appeal," Herald Scotland, www.heraldscotland.com/new/crimecourts (accessed 15 March 2017). The UK government now conducts LADO testing through its own representatives.

${ }^{84}$ See Patrick, "Language Testing of Asylum Seekers," for an in-depth explanation of Sprakab methods and their underpinning philosophy.
} 
Although Nafiz spoke Kibajuni in his interview, Sprakab concluded that he used an insufficient percentage of Kibajuni compared to Swahili to "prove" that he was Somali Bajuni. Brian Allen notes that information about the linguistic practices of the Somali Bajuni people has been found to be out of date, based on evidence given by elders who left the islands in the 1980s. ${ }^{85}$ In the meantime, life on the Bajuni Islands has changed. The Bajuni people have travelled further afield for trade and shelter, and their linguistic practices have broadened to include a greater portion of Swahili. ${ }^{86}$ The changing linguistic practices of the Bajuni people are informed by adaptations to the Bajuni lifestyle and experiences over the last 30 years. The testing to which the Nafiz was subject relied on an idea of language as a fixed and predetermined category. As we note in the literature review above, language, like other elements of intangible heritage, is subject to change-a characteristic enshrined in the provisions of the UNESCO ICH Convention. ${ }^{87}$ Moreover, international documents such as the UN Committee on Economic, Social and Cultural Rights's General comment no. 21 recommends treating "culture as a living process, historical, dynamic and evolving, with a past, a present and a future." 88 The elasticity of heritage, including linguistic heritage, thus has change at its core. By failing to take into account how Nafiz's language practice has evolved, the language tests disregard not only the processual nature of Bajuni linguistic practice as intangible heritage but also its legitimacy, applying the framework that led to the earlier definitions of heritage as static and unchanged. ${ }^{89}$

Since the beginning of its use by the UK government in the early 2000s, LADO testing has attracted significant criticism. The case for LADO testing was initially made by a number of academic linguists and linguist specialists, which accepted that through an analysis of a combination of their mother tongue, accent, and cultural knowledge of language use, it is possible to gain an indication of a person's place of origin..$^{90}$ However, while this scholarship suggests that LADO might be useful in providing an indication of a person's national/ethnic identity, it also stresses that results should not be treated as definitive. In addition, it recommends specific conditions in which the testing should be conducted, emphasizing that testing should be led by a linguistic expert with a basis in both language and cultural knowledge, and its conclusions should only be taken as guidance, not as fact. ${ }^{91}$

Unfortunately, as Nafiz's case above indicates, these caveats have been disregarded in practice. ${ }^{92}$ In place of a nuanced approach to language-practice that treats linguistic ability as elastic and only a partial indicator of a person's place

\footnotetext{
$\overline{{ }^{85} \text { B. Allen 2008, } 2 .}$

${ }^{86}$ Nurse, "Bajuni," 9.

${ }^{87}$ UNESCO ICH Convention, Art. 2.1.

${ }^{88}$ General Comment no. 21, Art. 11.

${ }^{89}$ Bortolloto 2007; Waterton 2010.

${ }^{90}$ Patrick, "Language Testing of Asylum Seekers."

${ }^{91}$ Patrick, "Language Testing of Asylum Seekers."

${ }^{92}$ Amnesty International 2012.
} 
of origin, LADO testing instead exhibits bad testing practice and has been (mis) shaped into a tool through which UK immigration authorities can make zero-sum decisions about the test results, their related asylum cases, and the applicants themselves. ${ }^{93}$ Rather than taking an approach that sought to unravel the complexities of Nafiz's and the other Bajuni campaigners' backgrounds, the UK immigration authorities instead began to use the tests to move towards a "blood and soil" logic that concluded that a person should speak in a particular way on account of their ethnicity. ${ }^{94}$ This essentialized notion of the relationship between ethnicity, linguistic practice, and identity goes against the recommendations of the progenitors of LADO testing. ${ }^{95}$ In Nafiz's case, this approach meant that in court he was judged on the logic that how one speaks is who one is, which, due to the circumspect results of his LADO tests, indicated to the immigration judge that he was not Bajuni and, therefore, not eligible for asylum.

The approach the judge took towards language, notably, was also contrary to the emphases of the UNESCO ICH Convention, which argues for an understanding of (intangible) cultural heritage as being practiced, elastic, and changeable. Building on Nafiz's experiences, one might therefore consider the relationship between the denial of his language, the denial of his asylum application, and the UK's absence from the UNESCO ICH Convention. Does the UK's absence from the Convention mean that Nafiz's flexible, elastic cultural heritage is unprotected? Does the UK's absence from the Convention therefore directly have an adverse effect on Nafiz's asylum application? And what of the status of language in this scenario? Given the current lack of provision for language in intangible cultural heritage instruments, to what extent would the UK's ratification of the UNESCO ICH Convention be of benefit to Nafiz's case? Taking the complexity of the Bajuni's situation into account, it is difficult to answer these questions with any certainty. However, they remain with us as we continue our discussion.

\section{A Question of "Evidence"?}

In Nafiz's case, the judge's approach to the relationship between intangible cultural heritage and identity was damaging enough to result in a final judgement against his asylum claim. However, the consequences of this approach feature throughout his case rather than solely in the final ruling. It can also be found in the ways in which immigration authorities privilege certain types of "evidence." For instance, in Nafiz's case, the judge relied upon "country guidance"-a report containing information about Somalia, compiled from research conducted by academics and non-governmental organizations (NGOs) — to make judgments about the veracity of Nafiz's claims. However, despite the weight given by the immigration judge to

\footnotetext{
933. Allen 2008; T. Allen 2013.

${ }^{94}$ Isin 2012, 450.

${ }^{95}$ Patrick, "Language Testing of Asylum Seekers."
} 
the report, it is not without issue. In the context of Bajuni asylum cases, a number of scholars and NGOs have raised concerns about the information contained in "country guidance" documents. ${ }^{96}$ Despite these inadequacies, in Nafiz's case, the judge continued to use the report to draw conclusions about Nafiz's language practices and ethnicity. Similarly, despite well-versed complaints against languagetesting practices, the judge also treated the test results as authoritative.

In the context of an asylum claim, it is not unreasonable for the judge to require evidence of a person's place of origin. However, in Nafiz's case, the judge appeared to give weight to the evidence and expertise of those with institutional-and, specifically, state-connections (LADO testing is a government initiative; country guidance is compiled by the Home Office). In part, this may be because this evidence and expertise appeals to a similar kind of logic that sees a person's ethnicity as being fixed. LADO tests, for instance, might appear to offer an almost "scientific" measure of a person's ethnicity and place of origin, while country guidance documents offer a closed and confident narrative of country-specific events that might be pertinent to a person's asylum application. In contrast, alternative forms of "evidence" fair badly. For instance, campaigner Faraaq's case relied upon detailed testimony formed from memories of his life on the island. However, because his testimony was emotive and based on individual experiences, it was considered unreliable. In similar circumstances, campaigner Mohamed had his linguistic testimony dismissed by an immigration judge on the basis of a LADO test. In reaction, and out of desperation, he decided to give his evidence to the judge in Kibajuni. With no other option open to him, he hoped that the living, speaking example of his linguistic ability would present sufficient "evidence" to the judge of his Somali Bajuni ethnicity. However, in a somewhat risible display of ethnic and linguistic inhospitality, ${ }^{97}$ the judge responded:

The appellant said that he was speaking in Kibajuni when he gave evidence before me. I found that to be an unsatisfactory way to proceed. As a Scotsman I can hardly know what language was being spoken. The appellant did not provide any expert report which could have assisted me. ${ }^{98}$

In a court setting, a lack of supporting, corroborating evidence to Faaruq's or Mohamed's claims would obviously be considered problematic. But, here, it is not only that the campaigners failed to satisfy a burden of proof but also that they tried to do so with evidence that the judge - and the immigration system-did not consider to be evidence. For instance, in Mohamed's attempt to give evidence of his linguistic and cultural heritage, the judge dismissed his submission because the type of evidence - a performance of living, linguistic heritage-did not correspond

\footnotetext{
${ }^{96}$ B. Allen 2008; T. Allen 2013; Amnesty International 2012; and Nurse, "Bajuni" have questioned the reports' information sources, the extent to which their information remains in date, and their treatment of language as a fixed category.

${ }^{97}$ Hill 2016.

${ }^{98}$ Private correspondence, 2014.
} 
with the terms of evidence to which the immigration system is calibrated. In Faaruq's case, his experience of Bajuni cultural heritage is doubted because it relies upon memory, local knowledge, and storytelling. In both cases, the type of evidence that the Bajuni campaigners sought to provide-and the way in which they attempted to provide it - was closely related to the performance of their intangible cultural heritage. However, because this "evidence" was informed by the type of qualities frequently associated with intangible cultural heritage-individual experience, embodied performance, changeable parameters—it did not fit within the immigration court's definition of "evidence" and, thus, was not seen as "evidence" at all. This has serious consequences for the Bajuni campaigners because, although they are able to provide a wealth of information about their lives as Bajuni people, the information they give is not considered to be of relevance to their cases and, in some instances, is detrimental to their success. There is an issue here not only of framing, but also of episteme, of what is considered knowledge and what is not.

The judge's scepticism of the type of evidence the Bajuni campaigners provide is perhaps indicative of a broader scepticism in the UK towards matters of intangible cultural heritage. Again, it is not possible to establish causality-that is, we cannot say that the judge's scepticism is the result of the UK's approach to intangible cultural heritage-however, it is not improbable that attitudes institutionalized in one faction of the state have influence on other factions. Consequently, we might suggest that dominant government attitudes toward protections that are specific to intangible cultural heritage have influence on other areas of statecraft, including the administration of the state's borders. Not bound by the UNESCO ICH Convention - and, without alternative, robust intangible cultural heritagespecific provisions-the current "authorized discourses" 99 of the UK encouraged the judge to treat the Bajuni campaigners' cases according to the rather fixed and inflexible definitions of cultural expression - an approach that failed to respond to the nuance of the campaigners' cases and for which the campaigners suffered.

\section{A Question of "Expertise"?}

Inevitably, the way in which the UK's immigration system questioned the authority of the Bajuni campaigners' "evidence" led to a questioning of the authority of the Bajuni campaigners themselves. In the examples above, as different immigration officers and judges cast doubt over both the Bajuni campaigners' evidence and nationality, their objections supported and returned to the question of "expert" knowledge. Although the judge could not be expected to have a working knowledge of Kibajuni, his treatment of Mohamed's Kibajuni performance was dismissive from the outset. Rather than simply reprimanding Mohamed, the judge might

\footnotetext{
$\overline{{ }^{99} \text { Smith } 2006 .}$
} 
have instead sought to explore the circumstances that prompted Mohamed's linguistic performance. Instead, startled by the absence of an "expert" witness or report-and, in part, because of this absence-the judge rebuked Mohamed. Meanwhile, despite Faaruq's wealth of experience of the Bajuni's cultural heritage, his knowledge was dismissed because it was not set out in the empirical terms of an "expert." Similarly, despite Nafiz's multilingual ability in Kibajuni and Swahili, his case was dismissed based on the account by "expert" testers. In their blog, the campaigners write:

Speaking about Bajunis and Kibajuni, [the authorities] call themselves as language experts but they know nothing about the language or tradition and culture of Bajunis. ... I don't think I can call myself an expert in front of someone who was born and grew up with the language or culture that I only learn from different books or through internet. ${ }^{100}$

In all of the Bajuni campaigners' asylum cases, the immigration authorities continually gave precedence to the evidence and expertise of those with institutional weighting and those already sponsored by the state. Their intangible cultural heritage practices were only accepted as "evidence" in their cases when they were seen to cohere to state frameworks - that is, only when they were defined by, tested against, and analyzed in the terms of the state-sponsored "experts." In many eventualities — and as is evident in the cases above-even if elements of intangible cultural heritage are accepted as "evidence," they continue to be found wanting in the context of asylum law.

For instance, Logan has noted that the ratification of the UNESCO ICH Convention can be detrimental to minority groups and communities because it means that the state can either prioritize one group over another or prioritize a dominant community over a minority group. He writes: "[G] overnments are responsible for the official lists and they generally define the official heritage to reflect what the dominant socio-political group or groups in a particular jurisdiction think is significant." 101 Our comments in this article have so far suggested that the Bajuni campaigners' cases have suffered from the fact that the UK has not ratified the UNESCO ICH Convention. However, in the context of the Bajuni campaigners' experience of narrative hierarchy, and with Logan's comments in mind, might we reconsider? Has the UK's absence from the Convention meant that the campaigners' cases have not been subject to the hierarchies of heritage that are endemic in the ratification of the Convention?

Unfortunately, this does not seem to be the case. The emphasis that the UK's immigration system places on certain types of "expertise" implies a hierarchy of authority and knowledge that sees the Bajuni campaigners' knowledge of their own intangible cultural heritage left with little purchase. As we have discussed, this is not an unusual occurrence; rather, the state has a history of occupying a

\footnotetext{
${ }^{100}$ Bajuni Campaign, 31 May 2014, Sprakab Scandal.

${ }^{101}$ Logan 2012, 236.
} 
similar position of power when it comes to defining heritage. ${ }^{102}$ Indeed, the Bajuni campaigners' cases appear to have been inserted into a hierarchy of heritage and expertise, even without the framework of the UNESCO ICH Convention. We find two possible explanations for this situation: (1) that, in contradiction to Logan's comments above, this has occurred because the UK is not a party to the UNESCO ICH Convention, which would perhaps encourage the state to consider further cultural heritage provisions for minority groups and communities or (2) that this is indicative of broader institutional attitudes toward the expression of minority groups and communities and is likely to occur regardless of the UK's positioning on the UNESCO ICH Convention. In this context, being in a state that has not ratified the Convention has not helped the Bajuni. However, taking into account the current limitations of the UNESCO ICH Convention, this is not to say that a converse situation-in which the UK had ratified the Convention-would present better circumstances for the campaigners, especially while language remains unaccounted for in intangible cultural heritage provisions.

\section{CONCLUSION}

The Glasgow Bajuni campaigners' cases expose shortcomings in (1) contemporary approaches to intangible cultural heritage by the UK immigration authorities and (2) the current provisions of the UNESCO ICH Convention. First, the campaigners' cases show that the lack of recognition given by the UK government of the need for specific provisions on intangible cultural heritage has influence and impact beyond the matters that overtly relate to heritage. Instead, as the campaigners' cases show, the emphasis of the UK government's dominant and "authorized discourse" on fixed and tangible heritage extends into other factions of statehood, including the immigration system, and allow for state representatives, including immigration judges, to advance state-supported scepticism over matters relating to intangible cultural heritage. While this may appear to be an indirect consequence of the UK's stance on intangible cultural heritage, in the context of the immigration system, in which this approach has the potential to grant or withhold asylum, matters become intensely politicized. In the Glasgow Bajuni campaigners' cases, the ideologies involved in establishing the limits of the UK state's "authorized" heritage discourse soon become closely related to establishing the limits of the UK state. In this situation, definitions and determinations of heritage must be seen in the state's vested interest in border maintenance and control.

Second, that in its current form, the UNESCO ICH Convention at best offers uncertain protection for groups such as the Glasgow Bajuni. There is certainly a case to be made that, if the UK were party to the UNESCO ICH Convention, the cultural heritage rights of the Glasgow Bajuni might enjoy more robust protection. Ratification of the

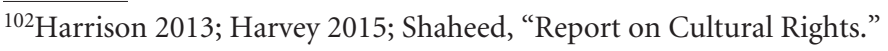


Convention might oblige other state actors (such as the immigration authorities) to consider the links between cultural heritage and human rights in ways they currently do not. It also might set a more general tone that might encourage state actors to consider matters of intangible cultural heritage without state-supported scepticism. However, there is also a case to be made that the UNESCO ICH Convention offers the Glasgow Bajuni campaigners little additional protection. The issue here is in the emphasis the Convention places upon the role of the state to identify and nominate instances of intangible cultural heritage on behalf of communities and groups. ${ }^{103}$ As Rodney Harrison observes, this means that communities and groups continue to be subordinated to the priorities of the state: "[G] roups are subsumed within nation-states and representations of their culture employed within broader nationalist discourses." 104 If the state continues to dominate representations of intangible cultural heritage, the experiences, concerns, and rights of minority groups and communities are likely to at best become occluded by state concerns. This applies especially to migrant and asylum-seeking groups, which are regularly the subjects of discourses about the limits of the nation. ${ }^{105}$ Moreover, at the margins of the state and marginalized in state interests, asylum-seeking groups have minimal access to rights and state provision. ${ }^{106}$ We would suggest that the UNESCO ICH Convention makes little provision for this type of dynamic.

These observations leave us with something of a conundrum. While the Glasgow Bajuni campaigners' cases have certainly not been helped by the UK's absence from the UNESCO ICH Convention, we would also question the extent to which they would benefit if the UK ratified the provision in its current form. For the Bajuni campaigners, this offers little relief from an already grim situation. At the time of writing, although the Bajuni campaigners continue to dispute both the refusal of their asylum cases and the grounds on which they were refused, they could not see how their cases might further be resolved. In a broader context, their cases prompt an urgent reconsideration of the provisions made by the UNESCO ICH Convention and ask whether there are any circumstances under which the Convention might be of future use to cases like that of the campaigners. The recent success of the American Declaration may provide some guidance. Developed with the close involvement of Indigenous peoples, it enshrines their rights to self-determination, multiculturalism, multilingualism and to "maintain, express and develop their cultural identity." 107 The Declaration is a rare instance in cultural heritage instruments in which the autonomy and selfdefinition of the peoples involved are foregrounded above the role of the state. Future developments of the UNESCO ICH Convention might therefore look

\footnotetext{
$\overline{{ }^{103} \text { Kuutma }} 2013$.

${ }^{104}$ Harrison 2013, 136.

${ }^{105}$ Hill 2016.

${ }^{106}$ Hynes 2011.

${ }^{107}$ Organization of American States, “17 Year Wait Pays Off for Indigenous People,” http://www.oas. org/en/media_center/press_release.asp?sCodigo=E-075/16 (accessed 14 November 2017).
} 
to the Declaration's emphasis on self-determination, cultural expression, and state minimization to address parallel gaps and limitations. We would also seek to push the implications of the Declaration a little further. The political and historical context that necessitates this Declaration is very different to that facing asylumseeking people in the UK. Remaining mindful of these differences, but recognizing the potential of the Declaration's precedent, we would therefore ask to what extent might it be possible to develop a similar instrument that makes provision for the cultural heritage rights of asylum seekers, and how might we better protect and support the intangible cultural heritage for those at the margins of the state?

\section{BIBLIOGRAPHY}

Abby, Abdi. 2005. Field Research Project on Minorities in Somalia. London: Oxford House.

African Union. 2006. Charter for African Cultural Renaissance. Addis Ababa, Ethiopia: African Union.

Ahmed, Ali Jimale. 1995. “'Daybreak Is Near, Won't You Become Sour?' Going Beyond the Current Rhetoric in Somali Studies." In The Invention of Somalia, edited by A. J. Ahmed, 157-90. Lawrenceville: Red Sea Press.

Allen, Brian. 2008. The Bajuni People of Southern Somalia and the Asylum Process. Dublin: Refugee Documentation Centre.

Allen, Tiffy. 2013. The Use of Sprakab Language Testing in Country of Origin Analysis, Particuarly for the Somali Bajuni. London: UK Parliament. publications.parliament.uk/pa/cm201314/cmselect/ cmhaff/71/71vw32008_HC71_01_VIRT_HomeAffairs_ASY-6.htm (accessed 24 May 2017).

Amnesty International. 2012. Submissions from Amnesty International Leeds Group for Universal Periodic Review 2012 of the United Kingdom of Great Britain and Northern Ireland: Treatment of Bajuni Asylum Seekers. Leeds: Amnesty International Leeds Group. lib.ohchr.org/HRBodies/UPR/ Documents/Session13/GB/AILG_UPR_GBR_S13_2012_AmnestyInternationalLeedsGroup_E.pdf (accessed 12 December 2017).

Besteman, Catherine. 1999. Unravelling Somalia: Race, Violence and the Legacy of Slavery. Pennsylvania: University of Pennsylvania Press.

Besteman, Catherine. 2012. "Translating Race across Time and Space: The Creation of Somali Bantu Ethnicity." Identities 19, no. 3: 285-302.

Bortolotto, Chiara. 2006. "From the 'Monumental' to the 'Living' Heritage: A Shift in Perspective." Paper presented at the conference World Heritage: Global Challenges, Local Solutions, Ironbridge Institute, Coalbrookdale.

Bortolotto, Chiara. 2007. "From Objects to Processes: UNESCO's 'Intangible Cultural Heritage'." Journal of Museum Ethnography, no. 19: 21-33.

Craig, Sarah. 2012. "The Use of Language Analysis in Asylum Decision Making in the UK: Discussion." Journal of Immigration Asylum and Nationality Law 26, no. 3: 255-68.

Donders, Yvonne. 2010. “Do Cultural Diversity and Human Rights Make a Good Match?” International Social Science Journal 61, no. 199: 15-35. 
Eno, Mohamed A. 2008. The Homogeneity of the Somali People: A Study of the Somali Bantu Ethnic Community. London: Adonis and Abbey.

Fairclough, Graham. 2009. "New Heritage Frontiers." In Heritage and Beyond, edited by Council of Europe, 29-41. Strasbourg: Council of Europe Publishing.

Griffiths, Melanie. 2012. “Vile Liars and Truth Distorters': Truth, Trust and the Asylum System.” Anthropology Today 28, no. 5: 6-10.

Hall, Stuart. 2005. "Whose Heritage? Un-Settling 'the Heritage', Re-imagining the Post-Nation." In The Politics of Heritage: The Legacies of 'Race', edited by J. Littler and R. Naidoo, 23-35. London: Routledge.

Harrison, Rodney. 2013. Heritage: Critical Approaches. London: Routledge.

Harvey, David C. 2015. "Heritage and Scale: Settings, Boundaries and Relations." International Journal of Heritage Studies 21, no. 6: 577-93.

Hassard, Frank. 2008. "Intangible Heritage in the United Kingdom: The Dark Side of Enlightenment?" In Intangible Heritage, edited by L. Smith and N. Akagawa, 270-88. London: Routledge.

Hill, Emma. 2016. "Welcoming Nations? Hospitality as a Proxy for National Identity: A Consideration of British and Scottish Contexts." In Public and Political Discourses of Migration: International Perspectives, edited by A. Haynes et al. Plymouth: Rowman and Littlefield.

Home Office. 2015. Country Information and Guidance: South and Central Somalia-Majority Clans and Minority Groups. London: UK Government. http://www.gov.uk/government/uploads/system/ uploads/attachment_data/file/566254/CIG_SOM_Clans_and_MGs.pdf (accessed 15 March 2017).

Howell, D. 2008. “The Intangible Cultural Heritage of Wales: A Need for Safeguarding?” International Journal of Intangible Heritage 8: 104-16.

Hynes, Patricia. 2011. The Dispersal and Social Exclusion of Asylum Seekers: Between Liminality and Belonging. Bristol: Policy Press.

Isin, Engin F. 2012. "Citizens without Nations.” Environment and Planning D: Society and Space 30, no. 3: 450-67.

Jokilehto, Jukka. 2012. "Human Rights and Cultural Heritage: Observations on the Recognition of Human Rights in the International Doctrine." International Journal of Heritage Studies 18, no. 3: 226-30.

Kapteijns, L. 2004. "I.M. Lewis and Somali Clanship: A Critique.” Northeast African Studies 11, no. 1: 1-23.

Kusow, Abdi M. 2004. "Contested Narratives and the Crisis of the Nation-State in Somalia: A Prolegomenon." In Putting the Cart before the Horse: Contested Nationalism and the Crisis of the Nation-State in Somalia, edited by in A. M. Kusow, 1-14. Trenton, NJ: Africa World Press.

Kuutma, Kristin. 2013. "Between Arbitration and Engineering: Concepts and Contingencies in the Shaping of Heritage Regimes." In Heritage Regimes and the State, edited by R. Bendix, A. Eggert, and A. Peselmann, 21-36. Göttingen: Universitätsverlag Göttingen.

Labadi, Sophia. 2010. "Introduction: Investing in Cultural Diversity." International Social Science Journal, no. 199: 5-13. 
Lixinski, Lucas. 2013. Intangible Cultural Heritage in International Law. Oxford: Oxford University Press.

Logan, William S. 2008. "Cultural Diversity, Heritage and Human Rights." In The Ashgate Research Companion to Heritage and Identity, edited by B. Graham and P. Howard, 439-54. Aldershot: Ashgate.

Logan, William. 2009. "Playing the Devil's Advocate: Protecting Intangible Cultural Heritage and the Infringement of Human Rights." Historic Environment 22, no. 3: 14-18.

Logan, William. 2012. "Cultural Diversity, Cultural Heritage and Human Rights: Towards Heritage Management as Human Rights-Based Cultural Practice." International Journal of Heritage Studies 18, no. 3: 231-44.

Logan, William, Michele Langfield, and Máiréad Nic Craith. 2010. Cultural Diversity, Heritage and Human Rights: Intersections in Theory and Practice. London: Routledge.

Mire, Hawa Y. 2016. "Somali Stories as a Site of Knowledge (Re/De)Construction.” Lecture given at the workshop entitled Re-imagining Somali Studies: Colonial Pasts, Postcolonial Futures, Harvard University, 15 April.

Nic Craith, Máiréad. 2008. "Intangible Cultural Heritages: The Challenge for Europe." Anthropological Journal of European Cultures 17, no. 1: 54-73.

Nic Craith, Máiréad, Ullrich Kockel, and Katherine Lloyd. Forthcoming. "The Convention for the Safeguarding of the Intangible Cultural Heritage - Practices and Policies." In Intangible Heritage, edited by L. Smith and N. Akagawa, 2nd ed. London: Routledge.

Nic Craith, Máiréad, and Emma Hill. 2015. "Re-locating the Ethnographic Field: From 'Being There' to 'Being There'." Anthropological Journal of European Cultures 24, no. 1: 42-62.

Phipps, Alison. 2013. "Intercultural Ethics: Questions of Methods in Language and Intercultural Communication." Language and Intercultural Communication 13, no. 1: 10-26.

Schuster, Liza. 2004. "Race, Immigration and Asylum: New Labour's Agenda and Its Consequences." Ethnicities 4, no. 2: 267-300.

Silverman, Helaine, and Fairchild D. Ruggles. 2007. "Cultural Heritage and Human Rights.” In Cultural Heritage and Human Rights, edited by H. Silverman and D. F. Ruggles, 3-29. New York: Springer.

Smith, Laurajane, 2006. Uses of Heritage. London: Routledge.

Smith, Laurajane, Emma Waterton, and Natsuko Akagawa. 2009. "The Envy of the World? Intangible Heritage in the United Kingdom." In Intangible Heritage, edited by L. Smith and N. Akagawa, 289-302. London: Routledge.

Stefano, Michelle L. 2016. “A Conversation with Richard Kurin.” In The Routledge Companion to Intangible Cultural Heritage, edited by P. Davis and M. L. Stefano, 40-45. Routledge: London.

Waterton, Emma. 2010. Politics, Policy and the Discourses of Heritage in Britain. Basingstoke: Palgrave Macmillan.

Zetter, Roger, David Griffiths, and Nando Sigona. 2005. "Social Capital or Social Exclusion? The Impact of Asylum-Seeker Dispersal on UK Refugee Community Organizations.” Community Development Journal 40, no. 2: 169-81. 